\title{
熟測定法による市販糖衣錠の崩壊測定*1
}

\author{
永瀬一郎, 藤代とし, 岡本尚子*2, 中島新一郎*3 \\ 千葉大学医学部付属病院薬郕部*2, 千葉大学薬学部*3
}

\section{Disintegration Measurement of Commercial Sugar-coated Tablets by Thermal Analysis*1}

\author{
ICHIRO NAGASE, TOSHI FUJISHIRO, TAKAKO \\ OKAMOTO, ${ }^{* 2}$ and SHINICHIRO NAKAJIMA*3 \\ Hospital Pharmacy, Faculty of Medicine, Chiba University*2, and \\ Faculty of Pharmaceutical Sciences, Chiba University*3
}

\begin{abstract}
The thermal analysis was applied to the quality control of tablets at hospital pharmacy. By using of twin type calorimeter with Dewar's vessels, disintegration and dissolution processes of 16 kinds of commercial sugar-coated tablets (11 kinds of single ingredient tablets and 5 of compound tablets) were examined in the acidic test solution. The results were compared with dissolution curves obtained by the UV method and disintegration time according to J. P. VIII. Thermogram showed various disintegration and dissolution patterns, and revealed intra- and interlot variations in the disintegration of tablets and aging effect on the disintegration of tablets. This method also made apparent the difference among disintegration processes which was not detected with dissolution curves and the gap between the disintegration times which could not observed by the disintegration test of J. P. VIII.
\end{abstract}

病院薬局に抢ける錠剤の品質管理の一手段としては日 局の崩壊試験法が広く行なわれているが, この方法は簡 便ではあるが主観が入りやすく，また溶出については全 く考慮されていない.薬剤の体内利用を考学る場合には 崩壊試験のみでは不十分であり，また bioavailability の観点からも近年溶出試験の重要性が強調されて種々の 試験法が試みられている．しかし有効成分の定量による 溶出試験では対象となる薬剤は限られ，また病院薬局で 日常的に多種類の錠剤について行ならことも困難であ る. そこで著者らは, 熱測定法によれば比較的簡便に錠 剂の崩壞 と溶出の全体像を知ることができる1)ことか ら，鋎剤の一般的品質管理の目的で熱測定装置の利用を はかり, 崩壊形式が多様であるといわれる市販糖衣錠に ついて熱測定を行ない検討した。 また溶出定量試験，日 局崩壊試験をもあわせて行ない，比較検討を加えたので 報告する.

*1 第 4 回日病薬関東学術大会（1974 年, 干葉）にて 発表

*2 千葉市亥且 1 丁目 8-1；8-1, Inohana 1-chome, Chiba-shi, 280 Japan

*3 干葉市弥生町 1-33；1-33, Yayoicho, Chibashi, 280 Japan

\section{実 驗 の 部}

\section{1. 熱測定装是および測定方法}

多重形恒温壁形双子熱量計 (応用電気研究所製作) 2 ) を使用した，原理は液中で発生する湿潤熱, 溶解熱, 反 応熱等の微小温度变化を熱電対によって電圧変化として 検出し, 同時にその電圧変化を電気的に微分して, 温度変 化一時間曲線とその微分曲線を 2 pen recorder により 記録し,これらの曲線の形状から崩壊時間, 溶出完了時 間等を求めるものである. 多重形装置では試料用セル 4 個が，攇汼熱消去のためのコントロール用セル 1 個とそ れぞれ双子熱量計を構成し, 出力端子のつなぎ替えによ って4 種の検体の連続測定ができるように設計されてい る. 図 1, 図 2 に双子熱量計のセルの内部構造とブロッ クダイヤグラムを示す. サンプルチューブはスプリング によって内側のシャフトを持ち上げていて, シャフトの 上端部を押し下げるとすり合わせのふたが開いて試料が 液中に落下する. 熱電対はクロメルーニンスタンタン, 銅一コンスタンタン各一対の直列使用で, 熱起電力は $100 \mu \mathrm{V} /{ }^{\circ} \mathrm{C}$ である. 感度は增幅器により $2 \times 10^{-3 \circ}$, 冷 却恒数は試験液 $120 \mathrm{~g}, 37^{\circ}$ で $0.002 \sim 0.005^{\circ} / \mathrm{min}$. であ った. スターラーの回転速度は $160 \mathrm{rpm}$ を用いた.

測定方法 サンプルチューブ内に錠剤を入れ, Dewar 

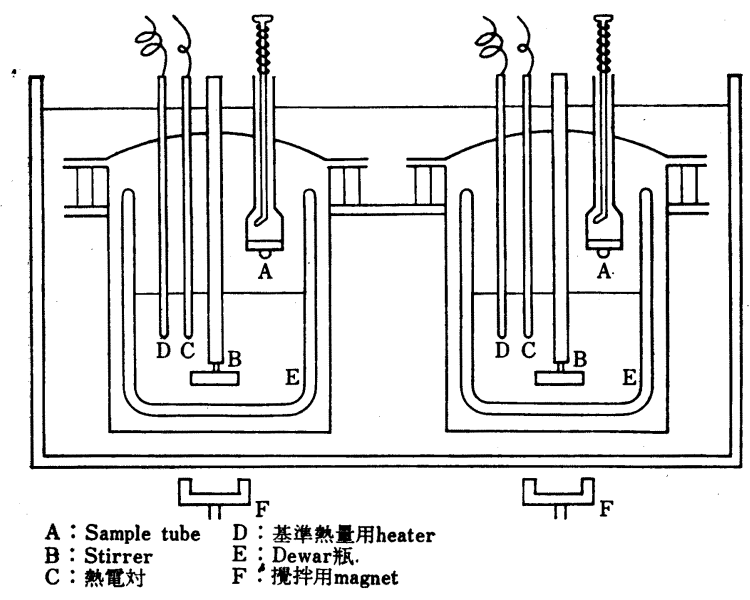

図 1 恒温壁形双子熱量計のセルの内部構造

瓶 (内容積 $360 \mathrm{~m} \ell$ ) に試験液 $120 \mathrm{~g}$ を入れて密閉し, 37 $\pm 0.05^{\circ}$ の恒温槽に沈め, 温度平衡に達した後錠剤を落 下させて温度変化曲線, 微分曲線を記録する.な揾度 平衝に達するまでの時間は約 12 時間である.

\section{2. 热測定装佂のセルを用いた溶出定目樲跧}

熱測定装置のセルの 1 つに試料採取管を取りつけ，熱 測定と同様に操作し, 試料落下後一定時間毎に試験液を 綿栓つきピペットで $1 \mathrm{ml}$ 宛採取してサンプルとし, 吸光 度測定により溶出曲線を求めた.

\section{JPUII 崩壤侙験器による崩壊および溶出樲硂}

富山産業製崩壊試験器 T 2 H型を用いた～ 5 鋔および 1 錠を用い, 試験液 $1000 \mathrm{~m} \ell$ で JPVIII に従って崩壊試験を 行ない, 併行して一定時間毎に綿栓つきピペットで試験 液を採取し，吸光度を測定して溶出曲線を求めた。

\section{4. 定是法}

定量はすべて紫外部吸収法により行なった，日立ダブ ルビーム分光光度計 124 型に日立レコーダー 056 型を連 動し記録させた．測定に用いた各製剤の主薬の吸収極大 波長を表 1 に示す.

\section{5. 铽㯺液}

すべて JPVII 崩壊試験法第一液を用いた。

6. 試料

市販糖衣錠のらちから表 1 に示すものを用いた。

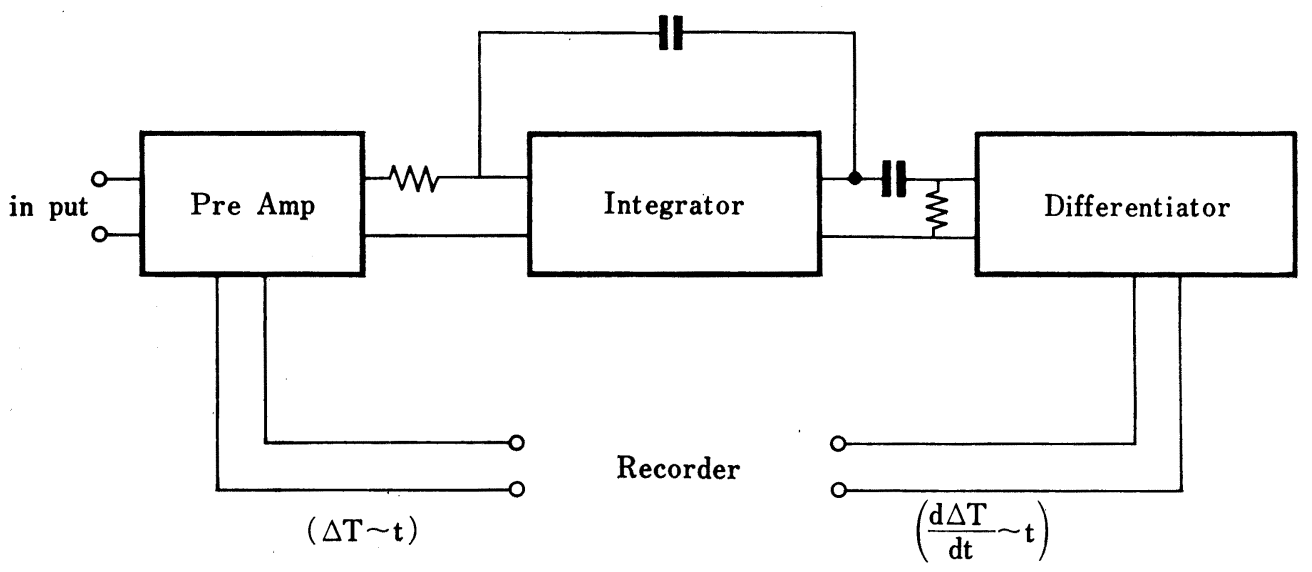

図2 恒温壁形双子熱量計ブロックダイヤグラム

\section{結果および考察}

得られた熱曲線は製剤により種々の形状を現わし，崩 壊様式の多様性を示している(図 3). 熱曲線では製剤に 使用されている添加剂, 賦形薬, 主薬等の熱的性質によ って吸・発熱が決まり, 崩壊溶出の時間経過によって変 化持続の長さが決まる. 従って曲線の形状のちがいから 添加剂等のちがいが推測され, また崩壊溶出の難易を知 ることができる．あらわれる熱変化の主なものは最外層 の白糖の溶解, dusting powder の崩壊あるいは第一液 中の塩酸との反応, 素錠の崩壊とそれと同時におこる溶 出などで，微分曲線のピークはそれぞれ対応する反応の
速度の最大となる点を示し, 基線への戻りが溶出の完了 点を示すと考えられている1．表 2 に各製剤の dusting powder の崩壊ないし第一液中の塩酸との反応速度の最 大点 $(\mathrm{Ta})$, 素錠の崩壊時間 $(\mathrm{Tb})$, 溶出完了時間 $(\mathrm{Tc})$ の 4 10 例測定による平均値を示す.

Optalidon, Vastarel F, Incidal, PZC, Contomin, Hustazol では崩壊溶出が迅速スムーズに進行している のに対し, Asthphyllin, Enbol では PZC 等と同様の 熱変化を示すが, 全体によりゆっくり進行していること が認められた. Pyrethia, Amisalin, Myobutazolidin では外層の崩壊から素錠の崩壊までにやや時間を要して 
病院薬学 Vol. 1, No.4 (1976)

表 1 試験に用いた糖衣錠

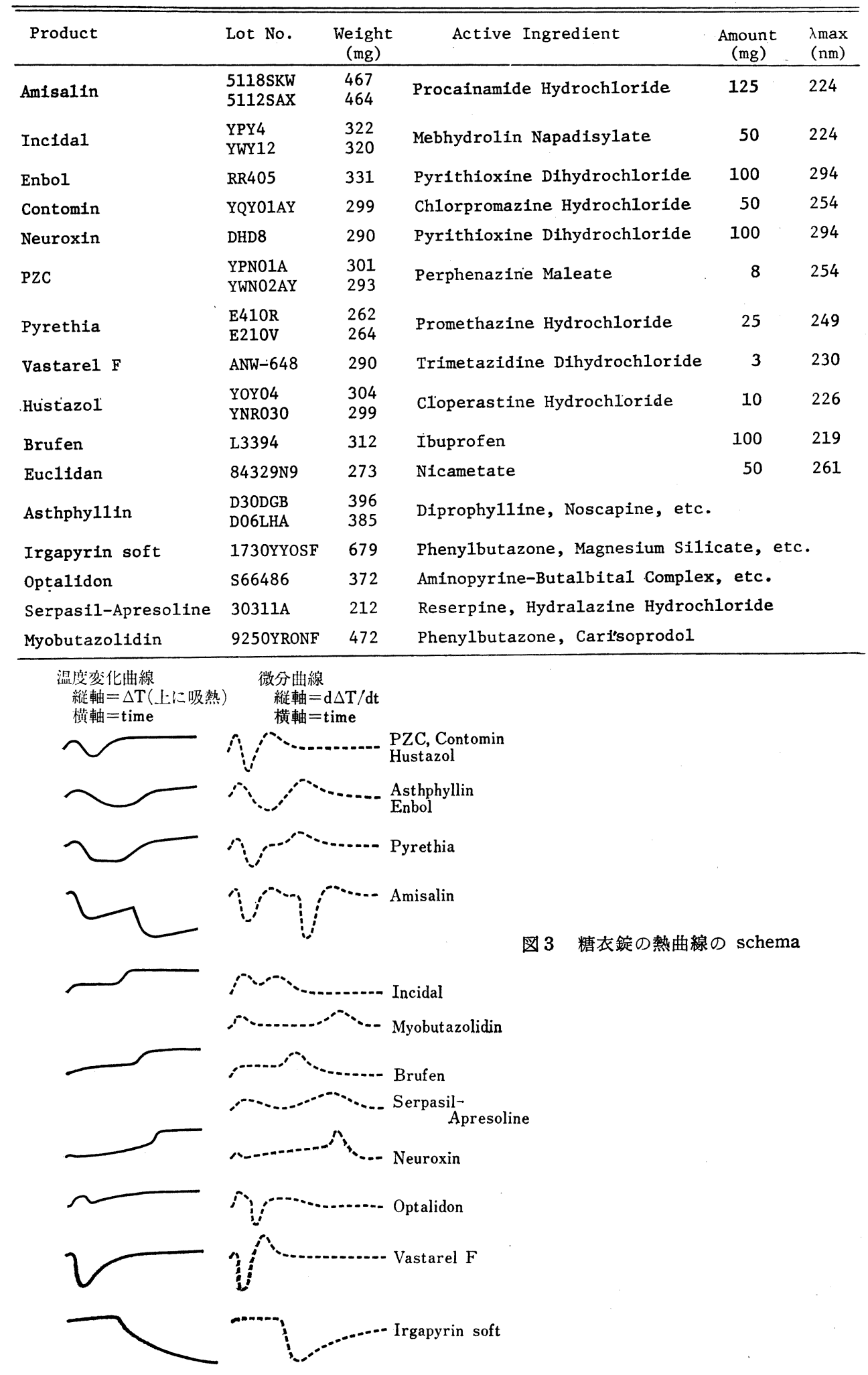


表 2 熱測定による崩噮・溶出時間, 定量法による溶出時間および局方崩萝時間（単位 min.）

\begin{tabular}{|c|c|c|c|c|c|c|c|}
\hline Product & Lot No. & $T_{a}$ & $T_{b}$ & $\mathrm{~T}_{\mathrm{c}}$ & $.50 \%$ & $t 100 \%$ & $\mathrm{JP}_{\mathrm{DI}}$ \\
\hline Amisalin & $\begin{array}{l}\text { 5118SKW } \\
5122 \mathrm{SAX}\end{array}$ & $\begin{array}{l}4 \\
4\end{array}$ & 24 & 70 & $\begin{array}{l}21 \\
26\end{array}$ & $\begin{array}{l}35 \\
70\end{array}$ & $\begin{array}{l}23 \\
24\end{array}$ \\
\hline Incidal & $\begin{array}{l}\text { YPY4 } \\
\text { YWY12 }\end{array}$ & $\begin{array}{l}2 \\
2\end{array}$ & $\begin{array}{l}8 \\
8\end{array}$ & $\begin{array}{l}15 \\
17\end{array}$ & 10 & 80 & $\begin{array}{r}9 \\
12\end{array}$ \\
\hline Enbo1 & RR405 & 7 & 13 & 31 & 8 & 18 & 11 \\
\hline Contomin & YQY01AY & 4 & 9 & 24 & 8 & 18 & 9 \\
\hline Neuroxin & DHD8 & & 18 & 22 & 9 & 20 & 10 \\
\hline PZC & $\begin{array}{l}\text { YPN01A } \\
\text { YWN02AY }\end{array}$ & $\begin{array}{l}4 \\
4\end{array}$ & $\begin{array}{l}9 \\
8\end{array}$ & $\begin{array}{l}1.8 \\
14\end{array}$ & $\begin{array}{l}8 \\
6\end{array}$ & $\begin{array}{l}25 \\
16\end{array}$ & $\begin{array}{l}9 \\
7\end{array}$ \\
\hline Pyrethia & $\begin{array}{l}\text { E410R } \\
\text { E210V }\end{array}$ & $\begin{array}{l}4 \\
5\end{array}$ & $\begin{array}{l}18 \\
18\end{array}$ & $\begin{array}{l}37 \\
30\end{array}$ & $\begin{array}{l}16 \\
14\end{array}$ & $\begin{array}{l}35 \\
27\end{array}$ & $\begin{array}{l}14 \\
14\end{array}$ \\
\hline Vastarel $\mathrm{F}$ & ANW-648 & 2 & 6 & 18 & 4 & 9 & \\
\hline Hustazol & $\begin{array}{l}\text { YOY04 } \\
\text { YNR030 }\end{array}$ & $3^{4}, 6$ & $\begin{array}{r}7 \\
10\end{array}$ & $\begin{array}{l}19 \\
20\end{array}$ & $\begin{array}{r}6 \\
10\end{array}$ & $\begin{array}{l}19 \\
20\end{array}$ & $\begin{array}{l}8 \\
9\end{array}$ \\
\hline Brufen & L3394 & & 14 & 23 & 15 & 40 & 21 \\
\hline Asthphyllin & $\begin{array}{l}\text { D30DGB } \\
\text { D06LHA }\end{array}$ & $\begin{array}{r}10 \\
8\end{array}$ & $\begin{array}{l}14 \\
13\end{array}$ & $\begin{array}{l}25 \\
28\end{array}$ & & & $\begin{array}{l}15 \\
13\end{array}$ \\
\hline Irgapyrin soft & 1730YYOSF & & 12 & & & & 10 \\
\hline Optalidon & S66486 & 1 & 4 & 17 & & & 5 \\
\hline Serpasil-Apresoline & $30311 \mathrm{~A}$ & & 19 & .23 & & & 11 \\
\hline Myobutazolidin & 9250YRONF & & 32 & 50 & & & 36 \\
\hline
\end{tabular}

Ta : 熱測定による dusting powder の崩壊, 反応の最大時間

$\mathrm{Td}:$ " 素錠崩壊時間

Tc： " 溶出完了時間

$\mathrm{t} 50 \% ， \mathrm{t}_{100 \%}$ ：熱測定装置のセルを用いた溶出定量試験による50\%，100\%溶出時間

JPDI：JPVIII 崩壊試験器による 5 錠崩壊時間

いる. Neuroxin, Serpasil-Apresoline では徐々に崩 壊が進み, ある程度進行した時点で一挙に崩壊したもの と思われる. また PZC, Pyrethia 等では, dusting powder と第一液中の塩酸との反応による発熱がみら れるのに対し, Incidal, Brufen 等ではみられない。 Irgapyrin soft では錠剂中の配合成分が第一液中の塩酸 と反応して大きな発熱を示したものと考えられ，熱変化 が大きくかつ持続するので, 微分曲線の基線への杘り点 は明確に求めることが困難であった. Euclidan では試 験したロットでは熱曲線上に崩壊がはっきりとはあらわ れなかった．熱測定装置のセルを用いての溶出定量でも 溶出はきわめて遅く, これは外層崩壊後皮膜をかぶった 素錠が残り, 穏やかな䚌汼条件と皮膜の強固さのため皮 膜が破れることなく，徐々に内部が湿潤したためと考兄 られた。

熱測定の再現性はきわめて良好であり，同一ロット内 での錠剤間のバラッキは一般に小さいことが認められ, Optalidon, PZC 等では殊に小さかった. PZC では熱 測定装置のセルを使用した溶出定量試験でも 5 例の溶出
曲線がほぼ重なった。図4に 4 VZC [Lot No. YWN02 $\mathrm{AY}]$ の熱曲線の 10 例くり返し測定中の 3 例および溶出 曲線 5 例中の 3 例を示す。 しかし Myobutazolidin で は素錠崩壊時間に多少のバラッキが認められ, Hustazo [Lot No. YNR030] では発熱ピークの形の間に差異が 認められた. Myobutazolidin の測定熱曲線 4 例を図 5 に示す. Myobutazolidin の局方崩壊試験法による崩壊 時間は 12 例の測定で18.5 35.5分（平均 25 分）であっ た. [Hustazol [Lot No. YNR030] とついて熱測定装置 のセルを用い， 5 例について溶出定量試験を行なった結 果, 溶出曲線の間にも差が認められた. 図 6 に Hustazol [Lot No. YNR030] の熱曲線 10 例測定中の 3 例および 溶出曲線 $\mathbf{5}$ 例を示す．以上にあらわれたような in vitro に打ける差が必ずしも in vivo 適用の際にも同様にあら われるとは考兄られないが，鋌剤品質管理上の目安にな るものと思われる.

ロット間の差については6製剤について試験した結果， PZC, Pyrethia, Incidal, Asthphyllin では熱曲線の形状 は2 種のロットで同じであり, 崩壊時間, 溶出完了時間 
にも大きな差は認められなかった。 しがし Hustazol で はロット間で熱曲線の発熱ピークの形が異なり崩壊様式 のちがいがうかがわれた。困7に Hustazol [Lot No.
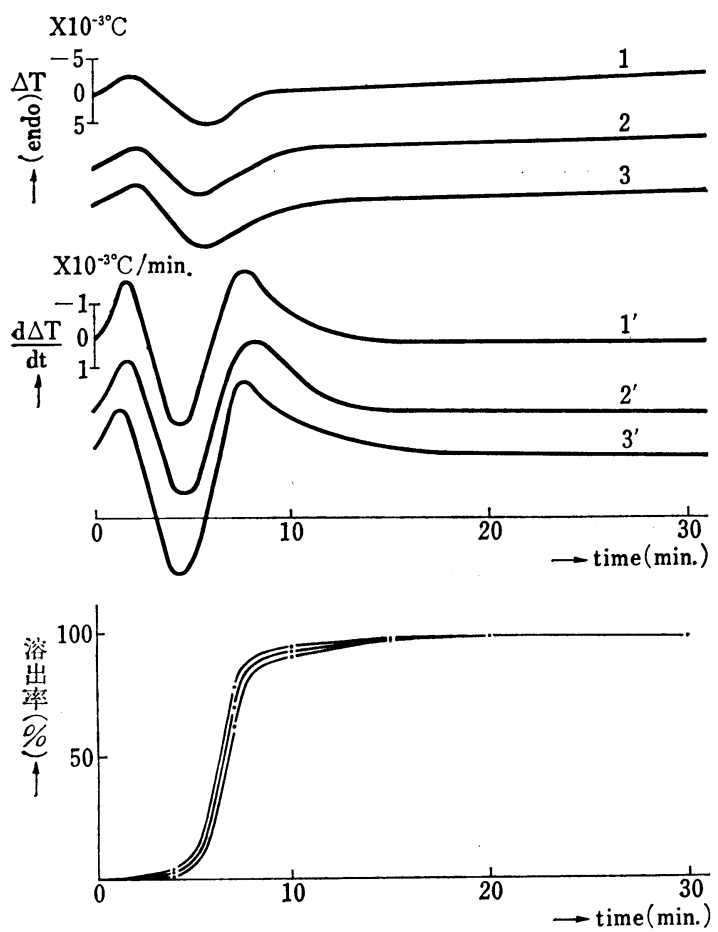

困 4 PZC [Lot No. YWN02AY] の熱曲線のくり返 し測定による比較と熱測定装圈のセルを用いた溶出曲線 微分曲線 $1^{\prime}, 2^{\prime}, 3^{\prime}$ はそれぞれ温度変化曲線 $1,2,3$ に 対応する. 熱曲線は 10 例測定中の 3 例，溶出曲線は 5 例測定中の 3 例を示す.

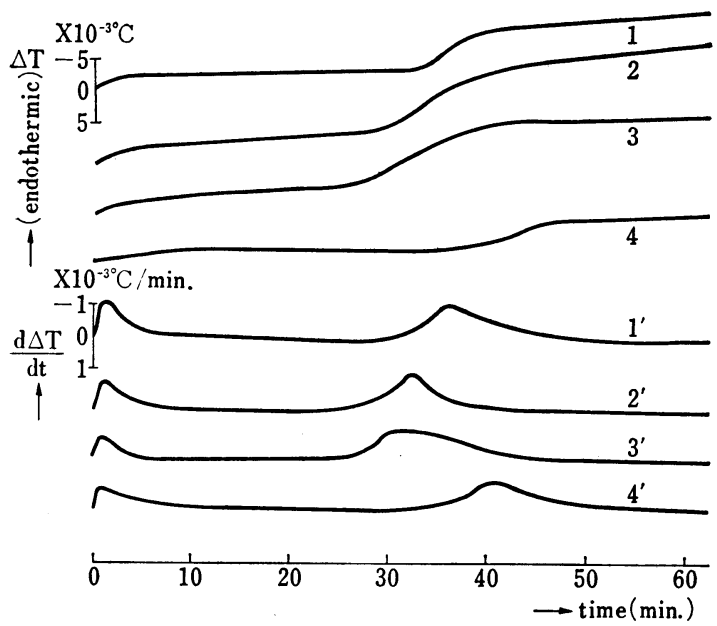

図 5 Myobutazolidin の熱曲線のくり返し測定による 比較

微分曲線 $1^{\prime}, 2^{\prime}, 3^{\prime}, 4^{\prime}$ はそれぞれ温度変化曲線 $1,2,3,4$ 亿対応する.
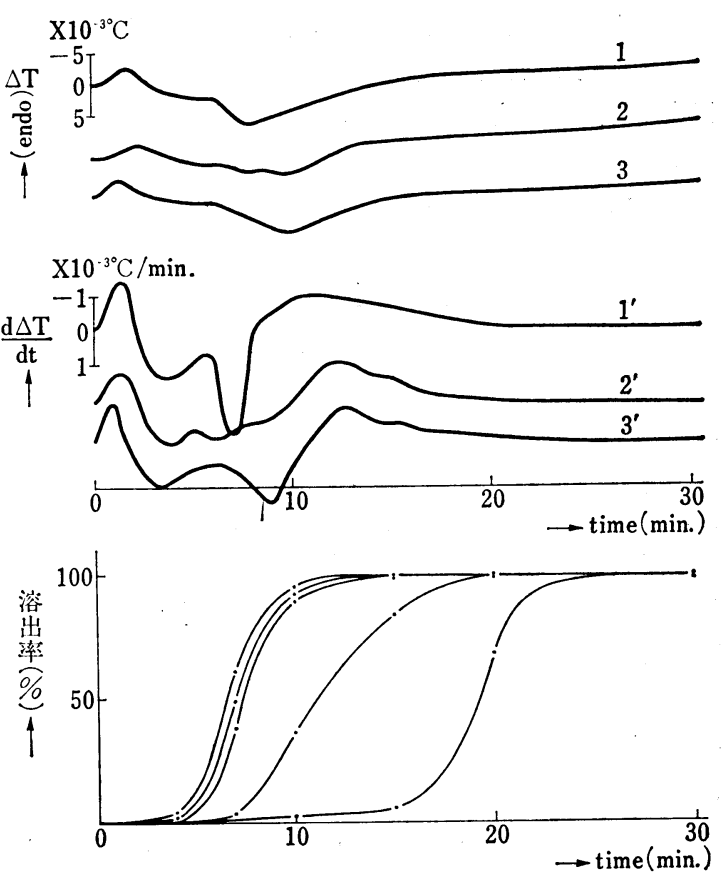

図 6 Hustazol [Lot No. YNR030] の熱曲線のくり返 し測定による比較と熱測定装置のセルを用いた溶出曲線 微分曲線 $1^{\prime}, 2^{\prime}, 3^{\prime}$ はそれぞれ温度変化曲線 $1,2,3$ 亿 対応する. 熱曲線は 10 例测定中の 3 例を示す.
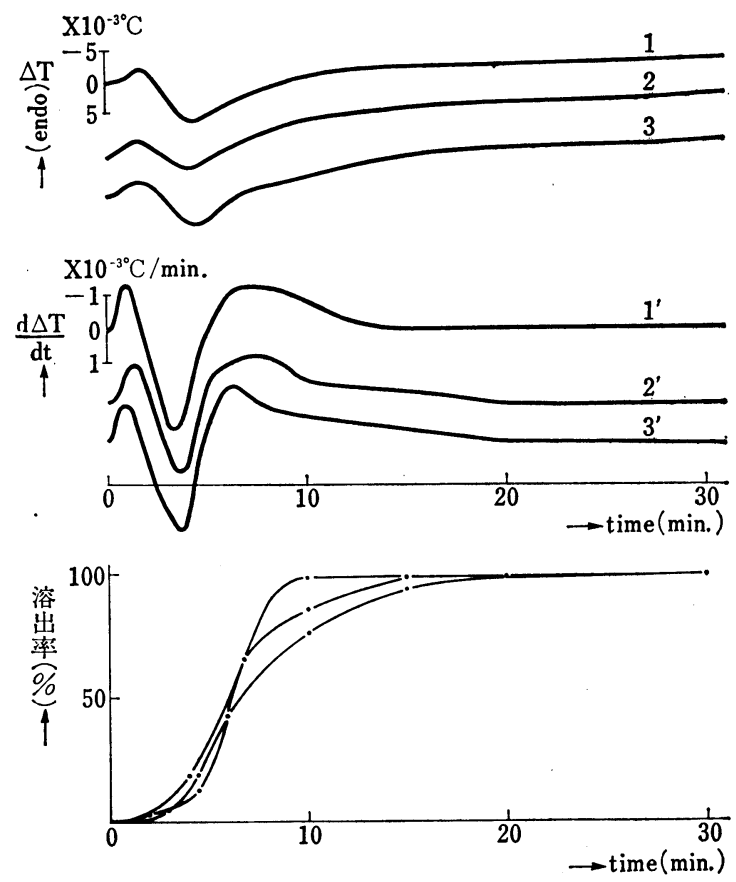

図 7 Hustazol[Lot No. YOYO4]の熱曲線のくり返 し測定による比較と熱测定装置のセルを用いた溶出曲線 微分曲線 $1^{\prime}, 2^{\prime}, 3^{\prime}$ はそれぞれ温度変化曲線 $1,2,3$ に対 応する. 熱曲線は 6 例測定中の 3 例を示す。 
YOYO 4] の熱曲線 6 例中 3 例, 溶出曲線 3 例を示す. 両ロット間で素鏔崩壊時間にはちがいが認められたが溶 出完了時間には差はなかった. Amisalin においては口 ット間の差が更にはっきりとみられた. Lot No. 5118 SKW では約 24 分で大きな素鏔崩壊ピークがあらわれ るのに対し, Lot No. 5122 SAX では素錠崩壊までの時 間が長びき，しかも明確な崩壊ピークを示さない。両口 ットの間にはあきらかに崩壊に差があり, Lot No. 5122 SAX で崩壊, 溶出が緩徐になっていることがわかる. 溶出定量試験によっても溶出の遅延が裹づけられたが, 局方崩壊試験では両ロットの間に差は認められなかっ た.この崩壊の遅延は素錠がかぶっている皮膜によるも のと思われ, 局方の崩壊試験器に上れば皮膜の崩壊が容 易におこるのに対し，熱測定装置のセルの攪拌条件では 困難であったものと考兄れる.

糖衣錠の崩壊溶出に対する aging の影響が報告され ている(h)が，市販錠についても経時的な崩壊の変化の 存在を知る目的で, PZC [Lot No. YWN02AY], Pyrethia [Lot No. E210V], Hustazol [Lot No. YNR030] についてシール包装のまま, $25^{\circ}, 81 \%$ R.H. に保存したものについて熱測定を行なった. PZC, Hustazol には 60 日間の保存後も変化は認められなか

(A)
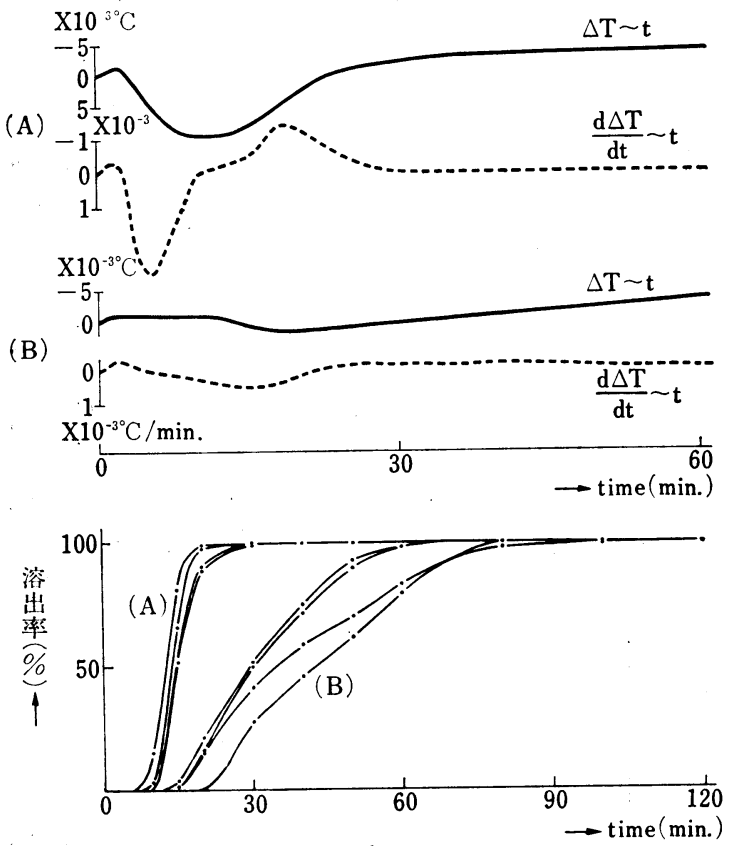

(A) : 開 封 時

(B) : $25^{\circ}, 81 \%$ R. H. 80 日間保存後

図 8 Pyrethia [Lot No. E210V] の経時変化:

熱曲線と熱測定装置のセルを用いた溶出曲線によ る比較
ったが, Pyrethia の 80 日間保存では熱曲線に変化が 生じ, 崩壊, 溶出の遅延が認められた. 熱測定装置の七 ルを用いた溶出定量試験でも同様に遅延が認められた。

図 8 亿経時変化前後の熱曲線の代表例と溶出曲線 4 例ず つを示す.

熱測定値と熱測定装置のセルを用いた溶出定量試験に よる溶出時間值とを比較すると, 崩壊, 溶出がスムーズ な PZC, Contomin, Hustazol, Incidal 等について は，素錠崩壊時間 $(\mathrm{Tb})$ と 50\% 溶出時間 ( $\mathrm{t} 50 \%$ ) お よび局方崩壊試験法による崩壊時間とがほぼ一致した.

一般には Tb は $\mathrm{t} 50 \%$ より遅い傾向にある. 熱曲線に よる溶出完了時間 $(\mathrm{Tc})$ と定量法による $100 \%$ 溶出時間 ( $\mathrm{t}$ 100\%) とでは，一致するものもあったが，一般に Tc の方が遅かった. これは熱曲線は主薬の溶出のみで なく他の熱変化要因をもとらえていること, 基線のわず かなずれが Tc 決定に影響を及ぼすことなどによってい ると思われる. Incidal, Brufen では $\mathrm{t}$ 100\%の方が Tc よ り遅かったが, これらは主薬が難溶性であるため, 素錠 崩壊後の熱变化が微小で緩徐となり, 発生した熱変化が 冷却恒数により相殺されてみかけ上早く溶出が終わった かのような様相を呈したものと思われる.

局方崩壊試験法との比較では, 局方崩壊時間は熱測定 の素錠崩壊時間とほぼ等しいか, あるいは早い值を示し ている. 熱曲線では崩壊ピークのみられなかった Euclidan む28 分で 5 錠全部が崩壊している. 局方崩壊試験 器を用いた溶出試験での $\mathrm{t} 50 \%, \mathrm{t} 100 \%$ も, 熱測定装置 のセルを使用した溶出定量試験で得られた $\mathrm{t} 50 \%, \mathrm{t} 100 \%$

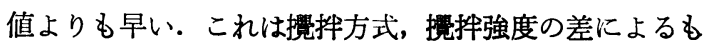
のと考えられる. 局方崩壊試験法は摫汼が激しすぎると もいわれていることから，熱測定装置による溶出がより 緩徐であることは, 本熱測定法が単に崩壊溶出の全体像 を示すのみならず, その細部についても局方崩壊試験器 を用いた溶出試験では差のあらわれない部分をる解析可 能とするものと思われる.

熱測定装置のセルを用いた溶出定量試験による $\mathrm{t} 50 \%$, $\mathrm{t} 100 \%$, および局方崩壊試験器による 5 錠の崩壊終了時 間をあわせて表 2 に示す.

熱測定法による糖衣䤥の崩壊, 溶出の過程, その製剤 特性を知ることができ, そのロット内, ロット間変動, あるいは経時変化等についても局方崩壊試験法ではとら えられない差異をも判別することができたままた単一成 分のみならず，配 合 錟刻の崩壊溶出過程をも測定しら る. 熱測定法は製剤中に含まれる個々の成分についての 知見を得るものではないので, 主薬の溶出については最 
終的には定量が必要となるが，1回の測定で崩壊と溶出 とを同時に知ることができるため, 錚風の品質管理に有 用な手段と考劣られる.

謝辞 終わりに, 種々の御教示を賜わりました千葉大 学薬学部仲井由宣教授に深謝いたします.

$$
\text { 交献 }
$$

1) a Nogami et al. : Chem. Pharm. Bull, 7, 331, 337(1959).

b Nakai, Kubo : Chem. Pham. Bull., 8, 634 (1960).

c Nakai : Chem. Pharm. Bull.,8, 641 (1960). d Nakai : Chem. Pharm. Bull., 9, 796 (1961).

e 仲井他：日本薬学会第 88 年会講演 要旨集, 9 (1968).

f 仲井他 : 日本薬学会第 90 年会講演要旨集 $\mathbb{N}-$ 14 (1970).

g 福沢他: 薬剤学, 30, 21 (1970).

h Nakai et al. : Chem. Pharm. Bull., 22, 2910 (1974).

2) 仲井他：日本薬学会第 91 年会講演 要旨 集 320 (1971).

抗生物質投与時にしばしば 下痢を見ることがありませんか？
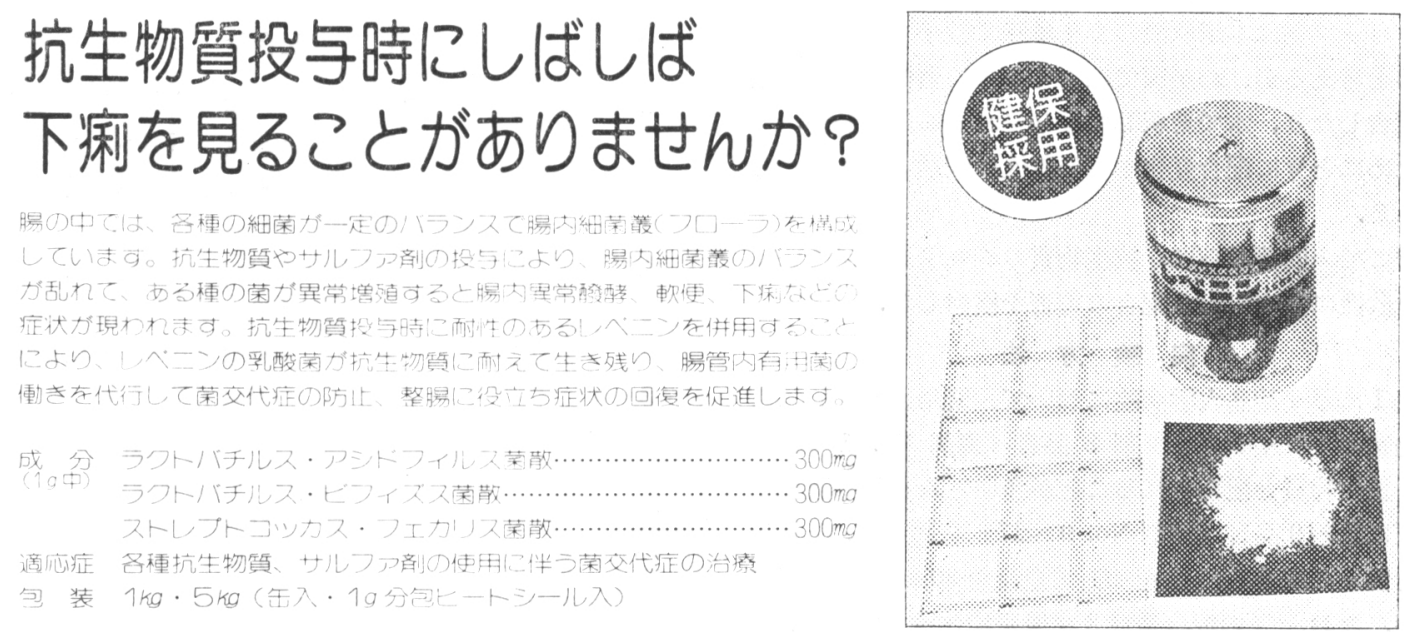

抗生物質耐性乳酸菌製剤
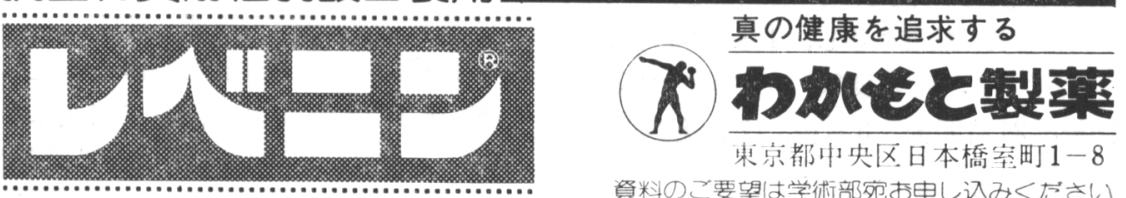

資料のご要望な学術部宛お申し込みください 